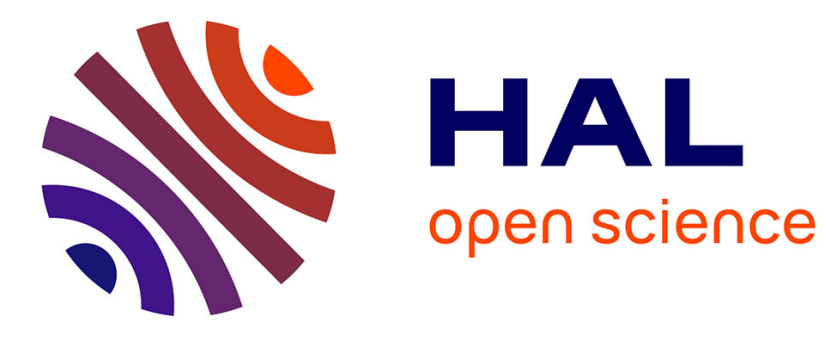

\title{
Modal Ellipsis in French, Spanish and Italian
}

Anne Dagnac

\section{To cite this version:}

Anne Dagnac. Modal Ellipsis in French, Spanish and Italian: evidence for a TP-deletion analysis.. Karlos Arregi, Zsuzsanna Fagyal, Silvina A. Montrul and Annie Tremblay. Romance Linguistics 2008: Interactions in Romance, 313, John Benjamins, pp.157-170, 2010, Current Issues in Linguistic Theory, 9789027248312. hal-00881807

\section{HAL Id: hal-00881807 \\ https://hal-univ-tlse2.archives-ouvertes.fr/hal-00881807}

Submitted on 31 Dec 2017

HAL is a multi-disciplinary open access archive for the deposit and dissemination of scientific research documents, whether they are published or not. The documents may come from teaching and research institutions in France or abroad, or from public or private research centers.
L'archive ouverte pluridisciplinaire HAL, est destinée au dépôt et à la diffusion de documents scientifiques de niveau recherche, publiés ou non, émanant des établissements d'enseignement et de recherche français ou étrangers, des laboratoires publics ou privés. 


\section{Modal ellipsis in French, Spanish and Italian}

Evidence for a TP-deletion analysis

Anne Dagnac

French, Spanish and Italian, reputedly non-VP-ellipsis allowing languages, can display gaps after root modals. I argue that these gaps are instances of ellipsis, viewed as PF-deletion of a constituent. They indeed allow for A'-movement, which an alternative null proform analysis cannot capture. Yet, they differ from English VP-ellipsis, in particular wrt the kind of remnants they allow, their tolerance to voice mismatches, and by displaying a constraint on subjects in Antecedent Contained Deletion. I propose that these differences follow from the status of the modals in these languages and the size of the deleted structure, which is a TP in the three Romance languages $v s$ a VP in English. ${ }^{1}$

\section{Introduction}

French, Spanish and Italian, unlike English, are classically held (cf. e.g. Lobeck 1995) not to allow for VP-ellipsis after auxiliaries, $c f$. (1) vs (2):

(1) a. ${ }^{\star}$ Tom avu Lee mais Marien' apas_. [Fr]

b. ${ }^{\star}$ Tom havisto Lee pero Maríano ha_.. [Sp]

c. ${ }^{\star}$ Tom havisto a Lee ma Marianon ha__. [It] Tom has seen (to) Lee, but Mary $\mathrm{Neg}^{2}$ has

'Tom saw Lee, but Mary didn't'

1. Special thanks to Jason Merchant, for his 2006 lectures in Paris that gave this work its seminal impulse and for later patient answers. Thanks, too, to J.Runner, L.Aelbrecht, D.Sportiche, S.Lappin, H.Demirdache, K.Johnson, the audiences of various talks including LSRL38, and two anonymous reviewers, for helpful comments, questions and/or answers. All errors are of course mine.

2. The French discontinuous negation ne...pas involves a scope marker (SM) ne and a negative word pas, which I subsume under NEG in the glose when giving similar Italian/Spanish examples.

\section{2nd proofs}


(2) John has gone to Paris but Alyson hasn't.

Yet, in these languages just as in English, root modals ${ }^{3}$ can be followed by a gap, interpreted in relation with an antecedent VP, $c f$. (3):

(3) a. Tomapu voir Lee, mais Marien'apaspu_. [Fr]

b. Tompudo vera Lee,pero María no pudo_. [Sp]

c. Tom ha potuto veder Lee, ma Maria non ha potuto_. [It]

Tom can:Pst see (to) Lee, but Mary NEG can:PST

d. 'Tom could see Lee but Mary couldn't_.'

In French, (3a) has been analyzed as an instance of VP-ellipsis (henceforth VPE) by Busquets and Denis (2001), who christen it 'Modal Ellipsis' and assume the PF-deletion analysis proposed for English (2/3d) ( $c f$., with variants, Hankamer and Sag 1976, Lappin 1996, Lasnik 2001, Johnson 2001, Merchant 2001, inter alia): a syntactically realized VP fails to be spelled out ('is deleted') at Phonological Form under identity with an antecedent VP, as featured in (4):

(4) [...Modal $\left[\ldots\left[{ }_{\mathrm{VP}} \mathrm{V}\left[\mathrm{DP}_{\mathrm{DP}} \ldots . ..\right]\right]\right.$

Conversely, Spanish and Italian sentences such as (3b-c) have been recently argued to involve null proforms (Depiante 2001, Cechetto and Percus 2006), i.e. unpronounced proforms devoid of inner syntactic structure, semantically interpreted like an overt pronoun, $c f$. (5):

(5) $[$...Modal $[\varnothing]]$

In Section 1, building on Busquets and Denis (2001), I show that French 'Modal Ellipsis' must indeed be analyzed as a syntactically structured gap. In Section 2, I provide empirical arguments that Spanish and Italian non-restructured root modals involve a similar ellipsis. In Section 3, I show that, nevertheless, French, Spanish and Italian ellipses depart from their English counterpart on several respects, which argue for the deletion of a higher constituent, namely a TP. In Section 4, I show how this proposal may also account for a constraint on their ACD constructions.

3. It is fully productive with ability and allowance modals, and possible, $c f$. (i), though restricted, with obligation ones, a fact I have no explanation for.

(i) J'ai lu tous les livres que je devais ('I read all the books that I had to')

Besides, $c f$. Depiante (2001), this possibility is restricted to 'non-restructured' instances of the modals. See note 9 for a tentative explanation.

\section{Arguments for a modal ellipsis in French}

A major diagnostic to distinguish between null proforms and ellipses is the (im) possibility to extract sub-items from the gap. Null proforms, being devoid of inner structure, cannot provide extraction sites for sub-items. On the contrary, if ellipsis is a deleted but otherwise 'normal' XP, any classical extraction from within this XP occurring before Spell Out is predicted to be possible.

In French, extraction facts clearly support the PF-deletion analysis: modal ellipsis allows for ACD, $c f$. (6), as first pointed by Busquets and Denis, but also for free relatives, $c f$. (7), and, under the same kind of contrast conditions found with English VPE (Park 2004, Merchant 2008b), for WH-questions, cf. (8):

(6) Léa lit tous les livres qu'elle peut <liret>. Lea reads all the books that she can.

(7) Il embrasse $\left[{ }_{W H} q u i_{i}\right]$ il peut <mbasser $t_{i}>$ He kisses $\left.\quad\left[{ }_{W H} \text { who(ever }\right)_{i}\right]$ he can $<$ kiss $_{t_{\mathfrak{i}}}>$ 'He kisses who(ever) he can'

(8) Je sais quels livres LEA peut lire et jesais aussi I know which books LeA can read and I know also quels livres. BEN ne peut pas $<$ lire $t_{\overrightarrow{\mathrm{t}}}>$. which books $s_{i}$ BEN SM can not $<$ read $\mathrm{t}>$.

'I know which books LEA can read and I also know which books BEN can't'

Whether ACD involves a classical relative operator or a copy of the head (Sauerland 2000,2004 , Fox 2002) in a matching/head raising analysis (cf. 6'), it requires an item to be moved from a base position inside the gap that a proform could not provide:

(6') Léa lit tous $\left[_{\mathrm{DP}}\right.$ les livres $\left[_{\mathrm{CP}}\left[_{\text {spec,CP }} \text { livres }\right]_{1}\right.$ qu'elle peut <lire [les [livres] $\left.]_{1}\right]>$ ]]

And so do free relatives and $W H$-questions. I assume that (7) involves $W H$-movement of the animate direct object qui (Rooryck 1994). In (8), quels livres ('which books'), must undergo movement from the direct object position of lire ('read') in the embedded clause.

That these constructions involve movement is confirmed by their island-sensitivity, $c f$. respectively (9), (10) and (11):

(9) *Bob a lu tous les livres que Léa partageait l'opinion qu'il Bob read all the books that Lea shared the opinion that nepouvait pas. he couldn't' 
(10) ${ }^{\star}$ Il finit toujourspar embrasser qui on se demandait He ends-upalways by kiss:INF who one REFL wondered $s$ 'il pourrait whether he could.

'He always ends up kissing who one wondered whether he could'

(11) ${ }^{\star} J e$ sais à qui jepeuxparler et jesais aussià qui I know to whom I can talk, and I know also to whom Marie partage l'opinion que je ne peuxpas.

Mary shares the opinion that IsM can not.

'I know to whom I can talk, and I also know to whom Mary shares the opinion that I can't.'

That a null proform cannot license them is further supported by their unavailability with an overt proform hosting no base-position for the moved item either, cf. $(12-14)$ :

(12) * Léa lit tous les livres qu'elle peutle faire/ qu'elle le peut Lea reads all the books that she can $\mathrm{it}=\mathrm{do} /$ that she $\mathrm{it}=\mathrm{can}$ 'Lea reads all the books that she can do it'

(13) ${ }^{\star} I l$ embrasse qui il peut le faire / qui il le peut

He kisses who he can it=do / who he it=can

'He kisses who(ever) he can do it'

(14) ${ }^{\star} J e$ sais quels livres Marie PEUT lire et jesais aussi I know which books Mary can read and I also know quels livres elle ne peut pas le faire.

which books she sm can not it=do'

A'-movement thus provides solid evidence that FME involves a fully structured though unpronounced XP. In the next section, I show that this conclusion extends to Spanish and Italian.

\section{Modal ellipsis beyond French}

Spanish and Italian similar gaps have been argued by Depiante (2001) and Cechetto and Percus (2006) to disallow extraction and hence to involve null proforms. This proves to be empirically wrong. ${ }^{4}$

4. Many thanks to Jaime, Enrique, Luisa, Zazil, Lucia, Fabio, Roberta and Andrea for patient discussions and judgements. My Spanish informants are from Galicia, Madrid, Andalucía and Mexico City, my Italian informants from northern Italy and Sardinia.

\subsection{ACD and the 'same subject constraint'}

Cechetto and Percus (2006) argue that Italian doesn't display ACD with modals on the basis of examples such as (15) (their[29b]), which I extend to Spanish in (16):

(15) ${ }^{*}$ Potrei mangiare ogni pizza che Gianni potrebbe. Could:1sg eat each pizza that Gianni could:3sg 'I could eat every pizza that Gianni could'

(16) *María lee todos los libros que Juan puede. Mary reads all the books that John can

This argument misses an important fact, though: in these examples, the subject of the modal (John) and the subject of the matrix clause (I, Mary) are referentially disjunct. But if both subjects corefer, ACD is perfectly grammatical in these languages, $c f$. (17) - a contrast also found in French, $c f .(17 c)$ vs $\left(17^{\prime}\right):^{5}$

(17) a. Maria legge tutti $i$ libri che può [Italian] b. María lee todos los libros que puede [Spanish]

c. Marie lit tous les livres qu'elle peut [French] Mary $_{\mathrm{i}}$ reads all the books that (she) can:3sg Mary reads all the books that she can'

(17’) ${ }^{\star}$ Marie lit tous les livres que Jean peut. Mary reads all the books that John can

3.2 Other A'-movements

Likewise, contra Depiante (2001), under the correct contrast conditions, $\mathrm{WH}$ questions are perfectly grammatical, $c f .(18-19)^{6}$.

(18) a. Ahora, ya sé a quién puedo confiar mi hijo,

b. Adesso, so a chi posso affidaremio figlio,

Now, (well) know:1sg to whom can:1sg confide my son,

pero todavía no sé a quién No puedo. [Sp]

ma non so ancora a chi NON posso. [It]

but (still) not know:1sG (still) to who NEG can1:SG

'Now, I know to whom I can confide my son, but I still don't know to whom I can't'

5. See Section 4 for an account.

6. Some informants require further contrast, on the $W H$-word or the modal itself. I ignore this point, since, crucially, given some contrast, they all admit $W H$-questions. 
Free relatives are licensed, too, $c f$. (19).

(1) a. Besa a quien puede. [Sp]

b. Baccia chi può. [It]

Kisses (to) who can:3sG

'S/he kisses who s/he can'

All these sentences involve A'-movement from the gap. Hence, Spanish and Italian pattern with French: their Modal Ellipses involve a deleted constituent. In the next section, though, I argue that they differ from English VP-ellipsis.

\section{Modal ellipsis is a TP-Ellipsis}

If French, Spanish and Italian modal ellipsis was indeed similar to English VPE, as proposed for French by Busquets and Denis, they should display parallel properties, which is partly not the case. I propose to link these differences to the status of their deontic modals. English modals are commonly viewed as auxiliaries selecting a vP/VP, $c f$. (20), and, following Merchant (2008a), as deleting a VP:

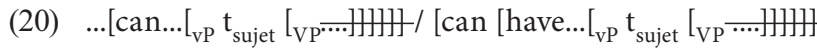

French, Spanish and Italian modals are subject-raising verbs argued to select a TP (see e.g. Wurmbrand 2001, and Ruwet 1972 for French), whith a general structure such as $(21):^{8}$

(21) $\left[_{\mathrm{VP}} \operatorname{modal}\left[\mathrm{TP}_{\mathrm{TP}} \mathrm{t}_{\text {sujet }}\left[\ldots . . . .\left[_{\mathrm{AspP}} \ldots\left[_{\mathrm{vP}} \mathrm{t}_{\text {sujet }}\left[\mathrm{VP}_{\mathrm{VP}} \ldots\right]\right]\right]\right]\right]\right]$

I propose that they target this TP for deletion. ${ }^{9}$

7. vs a vP (Johnson 2004, Merchant 2007) or a VoiceP (Baltin 2007). A reviewer points that it predicts wrongly that Floated Quantifiers can be remnants. In fact, as Sag (1978) already noted, the problem extends to high adverbs such as often or probably, and is not specific to ellipsis, since this ban extends to various pre-extraction positions. I follow Sag in assuming this is due to a phonological output constraint.

8. Other proposals all involve a complement bigger than VP, which would not crucially change the general argumentation.

9. According to e.g. Abeillé \& Godard (2003), Cardinaletti \& Shlonsky (2004), Romance restructuring modals (who ban ellipsis, $c f$. note 3 ) are auxiliary-like and select a vP/VP instead of a TP. They are then likely to disallow ellipsis for the same reason other auxiliaries do. This reason may be that the category of potential licensees for ellipsis is parametrical and deletion in these languages can target TPs but not vPs/VPs.

\subsection{Remnants}

Several elements can indeed intervene between the modal and the elided verb, among which aspectual and voice auxiliaries of the lower verb. In English, as expected if only VP elides, they can be left over by VPE, as shown respectively in (22) and (23):

(22) Paul managed to repair this stuff - Luke couldn't have < repared this stuff>

(23) The janitor should remove the trash whenever it is apparent that it needs to $b e<$ removed $\mathrm{t}>$

On the contrary, in French, Spanish and Italian, all projections above the elided VP must disappear, as shown for the aspectual head in (24) and the voice head in (25).

(24) a. ${ }^{*}$ Tompeut avoir fini en juin, et Lea peut aussiavoir. b. ${ }^{\star}$ Tom puede haber acabado en junio, y Lea también puede haber. c. ${ }^{\star}$ Tompuò aver finito ingiugno e anche Lea può avere. Tomcan have finished inJune and (also) Lea (too) can (also) have 'Tom can have finished in June, and Lea can have, too'

(25) a. *Paul peut être muté, et Kiko aussi peut être.

b. ${ }^{\star}$ Paco puede ser trasladado, y Kiko también puede ser.

c. ${ }^{*}$ Paolo può essere trasferito, e anche Kiko può essere. Paul can be transfered, and (also) Kiko (also) can be 'Paul can be transfered, and Kiko can be, too'

Assuming that 'have' is in AspP (Demirdache \& Uribe-Etxebarria 2002) and passive 'be' dominates either a VoiceP above vP (Collins 2005) or a vP with a passive feature, this is expected if modal ellipsis deletes the full TP, $c f .(26)$ :

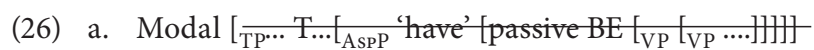

The case of negation is less straightforward. With English modals, the nontensed verb may marginally admit a negation, which doesn't survive ellipsis with modals, though, $c f$. (27). We assume that, like the negation following to in $\mathrm{He}$ tried to not win, it is an instance of constituent negation, contrary to the sentential negation that appears before to in He tried not to win and can escape ellipsis (Travis 2000), cf. (28b).

(27) a. She cannot resist temptation, and he cannot $\left[{ }_{V P}\right.$ NOT resist it.]

b. * She cannot resist temptation, and he cannot $<$ NOT resist it $>$.

(28) a. ${ }^{\star}$ He wanted to yield, but he tried $\left[_{\mathrm{TP}}\right.$ to $<\left[{ }_{\mathrm{VP}}\right.$ NOT yield $\left.]>\right]$

b. He wanted to yield, but he tried $\left[_{\mathrm{TP}}\right.$ NOT to $<_{\mathrm{VP}}$ yield $\left.>\right]$ 
Thus, the (higher) sentential negation in (28b) survives VP-ellipsis, whereas the constituent negation in (27b/28a), the only one available with modals, must disappear with the VP.

The three Romance languages can display a sentential negation on the infinitive clause, which is in a NegP above T (Zanuttini 2001) ${ }^{10}$. If TP is deleted, $c f .(30)$, it is predicted not to survive ellipsis, which is borne out, $c f$. (29)

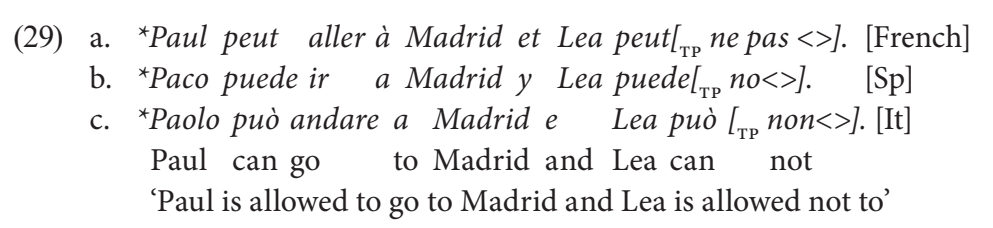

The different sizes of the deleted material in English VPE $v$ s 'Modal Ellipsis' thus capture the differences in the remnants allowed:

(30) a. Modal $\left[\overline{\mathrm{TP} \cdots}\left[(\mathrm{NegP} 1)\left[\mathrm{T} \ldots\left[\text { Asp }\left[\text { passive BE }\left[\left[_{\mathrm{VP}}\left[\mathrm{VP}_{\mathrm{VP}} \ldots . .\right]\right]\right]\right]\right]^{11}\right.\right.\right.$

b. Modal (Neg1) [Asp [passive BE $\left.\left[_{\mathrm{vP}}\left[_{\mathrm{VP}}(\mathrm{Neg}) \ldots . ..\right]\right]\right\}$

\subsection{Voice mismatches}

Another difference between the two constructions is their tolerance to voice mismatches between the elided constituent and its antecedent.

10. For French, $c f$. Zanuttini (2001): a NegP1 above T, hosting Spanish and Italian negations, also hosts the scope-marker NE. I leave open (and don't note in (30)), the exact location of the lower NegP hosting French PAS, since it is irrelevant here. I assume that the AgrS projection above NegP, necessary in tensed clauses to host the subject, is not projected in infinitive TPs following raising verbs.

11. A reviewer notes that this proposal correctly predicts (i), with a positive polarity particle on the infinitive, but not (ii) or (iii):

i. ${ }^{*} J u a n$ puede no llegar tarde al trabajo, pero Pedro puede sí Juan can not arrive late at-the job, but Pedro can 'yes'

ii. *Juan(no) puede no llegar tarde al trabajo, pero Pedro puede <llegartarde...> Juan (NEG) can not arrive late at-the job, but Pedro can

iii. ?Juan puede no llegar tarde al trabajo, pero Pedro sí puede<llegartarde...> Juan can not arrive late at-the job, but Pedro yes can

In fact, my proposal predicts (ii), since it violates the identity requirement on ellipsis: the two

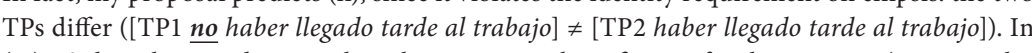
(iii), sí, though on poder, must have low scope on the infinitive for the sentence (in particular pero) to make sense. This suggests it has raised to a focus position in the matrix (before poder), which both enables it to be outside the elided site, and its trace/copy inside the gap to escape the parallelism requirement via focus (on this, see Section 4).
Voice mismatches are possible with English VP-ellipsis, under the right discourse conditions (Kehler 2000, Frazier \& Clifton 2006). In (31), the antecedent verb is active and the elided one passive; (32) illustrates the reverse case.

(31) The janitor must remove the trash whenever it is apparent that it should be <red $>$ (Merchant 2008a, [2b])

(32) This problem was to have been looked into, but obviously nobody did $<$ look into this problem> (Merchant 2008a, [1a])

On the contrary, Modal Ellipsis appears to rule them out, even in the same discourse conditions, as exemplified respectively for French, Spanish and Italian in $(35-36) .{ }^{12}$

(33) a. ${ }^{*}$ Ilfaut remplacerl'ampoule ${ }_{i}$ del'escalier, mais elle b. ${ }^{\star}$ Hayquecambiar la bombilla $a_{i}$ de la escalera, pero pro ${ }_{i}$

c. ${ }^{\star}$ Bisogna cambiare la lampadina ${ }_{i}$ della scala, ma pro $_{i}$ 'It needs' replace the bulb of the staircase, but it/pro ne peut pas <être remplacée $>$ - elle ${ }_{i}$ est coincée. no puede <ser cambiada> - pro ${ }_{i}$ se bloqueó. non può <essere cambiata> - pro $_{i}$ è bloccata. NEG can <be replaced> - it/pro ${ }_{i}$ is jammed /REFL jam:PST:3SG 'Someone should replace the bulb in the staircase but it can't - it's jammed'

(34) a. ${ }^{*}$ Ce problème aurait dî être résolu, mais

b. ??Questo problema avrebbe dovuto essere risolto, ma

c ?? Este problema debería haber sido solucionado, pero This problem must- be-PST-COND solved, but visiblement personnen'a pu. evidentemente nessuno ha potuto. pareceque nadie ha podido. obviously/appears that nobody (SM) can:PST.

'This problem should have been solved, but obviously nobody could.'

If Modal Ellipsis deletes more structure than VP-ellipsis, these facts may be given an explanation. Merchant (2008a) indeed notes that, cross-linguistically, VP-ellipsis allows for voice mismatches, whereas pseudo-gapping and sluicing rule them out. He proposes that in VP-ellipsis, only a VP being deleted, the v-head hosting the diverging voice feature remains outside of the ellipsis site. The material inside the elided VP thus complies to the usual identity requirement on

12. Some speakers seem to marginally admit the passive antecedent/active ellipsis cases. In any case, voice data need investigating as thoroughly as in English. 
ellipsis. With pseudo-gapping and sluicing, he argues, more material is deleted (respectively vP and TP). Hence, the diverging $\mathrm{v}$-heads are inside the ellipsis site and violate the identity condition.

If both his analysis and the data in (33-34) are right, the different tolerance to voice mismatches found in Modal Ellipsis and English VPE is straightfully accounted for by my proposal: in the latter, the deleted TP includes the diverging voice feature and thus violates the identity condition on ellipsis.

\section{Accounting for the 'Same Subject Constraint'}

Another puzzling difference is that ACD constructions are submitted to the 'Same Subject Constraint' ( $c f$. Section 2) in the three Romance languages, but not in English - cf. (35) vs (36), for the same context.

(35) [Tom is married to Lea, and he is blind: he cannot read. So, Lea reads aloud for him. In fact]

Lea reads every book that Tom can't (J.Merchant, p.c.)

(36) a. ${ }^{*}$ Lea lit tous les livres que Tom ne peut pas.

b. ${ }^{\star}$ Lea lee todos los libros que Tom no puede.

c. ${ }^{\star}$ Lea legge tutti $i$ libri che Tom non può.

Lea reads all the books that Tom NEG can

The TP-deletion hypothesis offers a way to account for this difference, too, as I shall show here for French. As is well-known, ellipses must comply to an identity condition. Its nature has been much debated, but a current formulation is that the content of the elided constituent must be semantically identical to its antecedent, modulo Focus-marked elements (for a technical implementation, see e.g. Merchant 2001). Within recent accounts of ACD (Sauerland 2000, 2004, Fox 2002), this requirement extends to traces, viewed as copies. Practically, this means that diverging elements (here the subjects) must either be outside the ellipsis site or be focussed.

Now, with an elided VP, such as in English (35), the trace of the subject is outside the elided site, $c f$. (37): it always evades the identity requirement.

(37) Lea reads every book $\left[{ }_{\mathrm{CP}}\right.$ book $_{2}$ that Tom can't $_{[\mathrm{VP}} \operatorname{Tom}_{1}\left\langle\left[\mathrm{VP}_{\mathrm{VP}} \text { read the book }\right]_{2}\right\rangle$

On the contrary, with a raising verb and a TP-ellipsis, as in (36) roughly detailled in (38), a copy of the subject is inside the ellipsis site. It must then either corefer with its antecedent, or be focussed. The SSC is then just a specific instanciation of the identity condition on ellipsis: if the infinitve subject corefers with the antecedent subject, $c f$. (39) the ellipsis is well-formed. If it doesn't, as in (36/38), it violates the identity condition and is then ruled out.

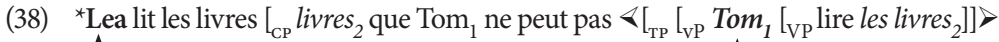



(39) Tom ${ }_{1}$ lit tous les livres $\left[_{\mathrm{CP}}\right.$ livres $s_{2}$ qu' il ${ }_{1}$ peut $\left\langle\left[_{\mathrm{TP} . . .}{ }_{\mathrm{vP}} i l_{1}\left[{ }_{\mathrm{VP}}\right.\right.\right.$ lire les livres $\left.\left.\left._{2}\right]\right]\right\rangle$

Tom reads all the books that he can he read the books

'Tom reads all the books that he can'

Its only way to avoid ill-formedness in this case is to be F-marked. This, we claim, happens in conjuncts, $c f$. (40), where all F-marking devices (De Cat 2004), in particular left-dislocation and narrow focus intonation on DPs, are available to mark subjects:

(40) (Context: Which neighbors can come?)

Paul peut venir mais Marie ne peut pas. mais Marie) $\left.)_{\mathrm{RG}} \mathrm{L} \%\right]_{\mathrm{IntP}}$ ne peut pas) $\left.{ }_{\mathrm{RG}} \mathrm{L} \%\right]_{\mathrm{IntP}}$.

Paul can come but MARIE SM can not

So, why can't subjects also resort to F-marking in ACD constructions? Because, we claim, restrictive relatives are not on the same information level as their main clauses: be they elided or not, the proper ways to F-mark subjects are not available for them. This is the case with contrastive topics, marked by left dislocated subjects, which require parallel information structures (Gergel et al. 2007): ${ }^{13}$

(41) ${ }^{\star}$ Lea lit tous les livres que Tom, il ne peut pas lire. Lea reads all the books that Tom, he SM can not read 'Lea reads all the books that том can't read'

(42) ${ }^{\star}$ Lea lit tous les livres que Tom, il ne peut pas. Lea reads all the books that Tom, he sM can not 'Lea read all the books that том can't'

DP subjects with a narrow focus intonation $c f$. (43), or with a focus-sensitive particle as in (44), are also impossible in non-elided restrictive relatives, as the subject can't correspond to the $\mathrm{WH}$-part of a related question, contrary to what happens to the conjunct in (40) - only Lea, the main subject, can:

(43) Lea lit tous les livres que Tom ne peut pas lire

$$
\begin{aligned}
& \text { a. } \left.\left.\quad \text { \#Tom) })_{R G} L \%\right]_{\text {IntP }} \text { ne peut pas lire) }{ }_{R G} L \%\right]_{I n t P} \\
& \text { b. } \left.\quad \text { Tom) }{ }_{R G} \text { n'a pas pu lire) }{ }_{R G} L \%\right]_{I n t P}
\end{aligned}
$$

13. Imponing such a focus structure on the relative may be possible but turns it into a nonrestrictive one, irrelevant here.

\section{2nd proofs}


(44) ${ }^{\star}$ Lea lit tous les livres que Tom aussipeut lire

${ }^{*}$ Lea reads all the books that Tom also can read.

So, in the elided relative in (36/38), the subject has no way out: the narrow focus intonation that would F-mark the disjunct subject ( $c f .45 \mathrm{a}$ ) is ruled out just as in its non-elided version in (43a). Only the broad focus intonation found in (43b) is possible, but it doesn't F-mark the subject, and (45b), the elided version of (43b), violates the identity condition.

(45) ${ }^{\star}$ Lea lit tous les livres que Tom ne peut pas.

$$
\begin{array}{ll}
\text { a. } & \left.\left.\left.{ }^{*} \text { Tom }\right)_{\mathrm{RG}} \mathrm{L} \%\right]_{\text {IntP }} \text { ne peut pas) }{ }_{\mathrm{RG}} \mathrm{L} \%\right]_{\mathrm{IntP}} \\
\text { b. } & \left.{ }^{*} \text { Tom) }{ }_{\mathrm{RG}} \text { ne peut pas) }{ }_{\mathrm{RG}} \mathrm{L} \%\right]_{\mathrm{IntP}}
\end{array}
$$

No device to (properly) F-mark subjects being available in restrictive relatives, ACD subjects can only corefer to the antecedent subject not to violate the general identity condition on ellipsis. ${ }^{14}$ Since this unavailability stems from the infornational status of restrictive relatives, Spanish and Italian are then expected to show such a restriction.

\section{Conclusion}

French, Spanish and Italian pattern together in licensing, after modals, gaps that display a full range of island-sensitive extractions, in particular relativization and $W H$-movement, as long as the relevant semantic constraints are met. This casts strong doubt over a null proform analysis, that would be unable to provide a base position for the moved items. But they also differ from English VP-ellipsis: they cannot strand any item higher than VP, they display the 'Same Subject Constraint'

14. To my knowledge, the constraint on subjects in ACD modal ellipsis had gone unnoticed so far. The data and this first proposal may need refining. Some speakers seem to unevenly accept some cases of disjunction. One reviewer finds (i), marginally acceptable.

(i) ?A Juan le gusta comer todo lo que Pedro no puede

Its French counterpart (ii), with an infinitive in subject position, is also marginally acceptable, and some French speakers accept (iii), where the relative subject is a contrastive pronoun with a somewhat underdocumented status:

(ii) 'Manger tout ce que Lea ne peut pas plaît beaucoup à Tom

(iii) \%Je porterai tous les cartons que Lur ne peut pas.

These cases may suggest that the status of the subject/antecedent matters for the proper formulation of identity conditions, or that the claim that subjects can't escape identity via focus in restrictive relatives is too strong: some kind of F-marking (but not all) may be available to contrast (some types of) subjects in ACD constructions. If our proposal can be maintained, this constitutes a field of investigation per se. in ACD and they rule out voice mismatches. I propose that all these differences stem from the fact that 'Modal Ellipsis' deletes a TP while English VPE deletes a mere VP, a direct consequence of the different status of the modals in these languages. The SSC consists in the extension of the usual identity condition on elided material to the copy of the raised subject. Within this view, Lobeck's (1995) claim that these Romance languages don't display VPE remains fully grounded: they only allow for TPE. But the existence of an instance of TP-ellipsis with (nonauxiliary) deontic modals brings new material to the on-going debate on how ellipsis is licensed.

\section{References}

Abeillé, Anne \& Danielle Godard. 2003."Les Prédicats complexes dans les langues romanes". Les Langues romanes: problèmes de la phrase simple. 125-184. Paris: CNRS Editions.

Baltin, Mark.2007. “Deletion Versus Pro-Forms: A False Dichotomy?”. Ms., New York University. Busquets, Joan \& Pascal Denis. 2001. "L'Ellipse modale en français: le cas de pouvoir et devoir". Cahiers de Grammaire26. 55-74.

Cardinaletti, Anna \& Ur Shlonsky. 2004. "Clitic Positions and Restructuring in Italian". Linguistic Inquiry 35:4. 519-557.

Cecchetto, Carlo. \& Orin Percus. 2006."When we do that and When we don't: a contrastive analysis of VP-ellipsis and VP-anaphora”. Phases of Interpretation, ed. by M. Frascarelli. 71-105. Berlin/New York: Mouton de Gruyter.

Collins, Chris. 2005. “A Smuggling Approach to the Passive in English”. Syntax 8:2. 81-120.

DeCat, Cécile. 2004. "Early Pragmatic Competence and its implication regarding the null subject phenomenon". Romance Languages and Linguistic Theory 2002 ed. by R.Bok-Bennema et al. 17-32. Amsterdam/Philadelphia: John Benjamins.

Demirdache, Hamida \& Miriam Uribe-Etxebarria. 2002. "La Grammaire des prédicats spatiotemporels: temps, aspect et adverbes de temps". Temps et Aspect ed. by Brenda Laca. 125-176. Paris: Presses Universitaires de Vincennes.

Depiante, Marcela. 2001. "On Null Complement Anaphora in Spanish and Italian”. Probus13. $193-221$

Fox, Danny. 2002. "Antecedent Contained Deletion and the Copy Theory of Movement". Linguistic Inquiry 33: 63-96.

Frazier, Lynn \& C. Clifton. 2006. Ellipsis and Discourse Coherence. Linguistics \& Philosophy 29: $315-346$.

Gergel, Remus et al. 2007. "Ellipsis and Inversion: a feature-based approach".On Information Structure, Meaning and Form, ed. by Kerstin Schwabe \& Susanne Winkler. Amsterdam/ Philadelphia: John Benjamins.

Hankamer, Jorge \& Ivan Sag. 1976. “Deep and Surface Anaphora”. Linguistic Inquiry 7:3. 391-428. Johnson, Kyle. 2001. "What VP Ellipsis Can Do, and What it Can't, but not Why". The Handbook of Contemporary Syntactic Theory ed. by Mark Baltin and Chris Collins. 439-479. Blackwell Publishing.

Johnson, Kyle. 2004. “How to be Quiet”. Ms, University of Massachusets. 
Kehler, Andrew. 2000. "Coherence and the Resolution of Ellipsis". Linguistics and philosophy23: 533-575.

Lappin, Shalom. 1996. "The Interpretation of Ellipsis". The Handbook of Contempory Semantic Theory, ed. by Shalom Lappin. 145-175. Blackwell Publishing.

Lobeck, Anne. 1995. Ellipsis: Functional Heads, Licensing and Identification. New York/Oxford: Oxford University Press.

Merchant, Jason. 2001. The Syntax of Silence. New York/Oxford: Oxford University Press.

Merchant, Jason. 2007. "Voice and Ellipsis". Ms, University of Chicago.

Merchant, Jason. 2008a. "An asymmetry in voice mismatches in VP-ellipsis and pseudogapping”. Linguistic Inquiry 39:1. 169-179.

Merchant, Jason. 2008b. "Variable Island Repair under Ellipsis". Topics in Ellipsis, ed. by Kyle Johnson. 132-153. Cambridge/New York: Cambridge University Press.

Park, Myung-Kwan. 2004. "Phases, cyclicity, and extraction out of ellipsis in English". Studies in Generative Grammar 14: 4. 469-497.

Rooryck, Johann. 1994. "Generalized Transformations and the WH-cyle: free relatives as bare WH-CPs". Minimalism and Kayne's Asymmetry Hypothesis, ed. by Jan-Wouter Zwart. Groningen: University of Groningen. 195-208.

Ruwet, Nicolas. 1972. Théorie syntaxique et syntaxe du français, Paris: Seuil.

Sag, Ivan. 1978. "Floated Quantifiers, Adverbs, and Extraction Sites". Linguistic Inquiry9:2. $146-150$

Sauerland, Uli. 2000. "Obligatory reconstruction and the meaning of traces". Arbeitspapiere des SFB 340, Bericht Nr153. 1-28.

Sauerland, Uli. 2004. "The Interpretation of traces". Natural Language Semantics 12. 63-127. Wurmbrand, Susanne. 2001. Infinitives: Restructuring and Clause Structure. Berlin/New York: Mouton De Gruyter.

Zanuttini, Raffaella. 2001. "Sentential Negation". The Handbook of Contemporary Syntactic Theory ed. by Mark Baltin and Chris Collins. 511-535. Blackwell Publishing.

\section{Optional prepositions in Brazilian Portuguese}

\author{
Mary A. Kato
}

This paper discusses the phenomenon of preposition optionallity in Brazilian Portuguese (BP), starting from Bouchard's (1981) observation that the preposition of a strictly subcategorized PP complement in French can be absent in the "chopping" type of relativization, though the same sort of "deletion" is ruled out in $w h$-questions, a contrast that leads him to propose that movement is absent in such relatives. My aim in this paper is (a) to show that this phenomenon is not restricted to relative clauses, (b) to propose a uniform analysis of preposition optionallity in several domains, (c) to argue that prepositions which encode inherent case are optional in the numeration, and (d) to claim that absence of the preposition involves only A'-positions, where the DP can have a "default" case. The paper ends up with a discussion on contrastive topicalization, assumed to be derived from VP-topicalization.

\section{Introduction}

The phenomenon of optional prepositions in Brazilian Portuguese (BP) has been extensively studied in Tarallo's (1983) work on relative clauses, inspired by Bouchard's (1981) paper on a similar phenomenon in French.

The aim of the present study is to show that this phenomenon is not restricted to relative clauses, and to propose a uniform analysis of this optionallity in several domains: topic positions, relative clauses, and cleft constuctions. The research questions are the following:

a. what sort of prepositions can be optional in BP?

b. what positions license optionallity of prepositions in BP and why?

This paper had the support of CNPq grant 301219/2008 and FAPESP 2006/00965-2. thank the valuable contributions of Juanito Avelar. Heloisa Salles, Jairo Nunes, Marcello Marcelino and Paulo Medeiros. I also owe an enormous debt to Bouchard's comments on the first version of the paper. The usual disclaimers apply.

\section{2nd proofs}

